\title{
REGIONAL DISPARITIES, ABSORPTION CAPACITY AND STRUCTURAL FUND PAYMENTS: A CASE STUDY OF THE CZECH REPUBLIC
}

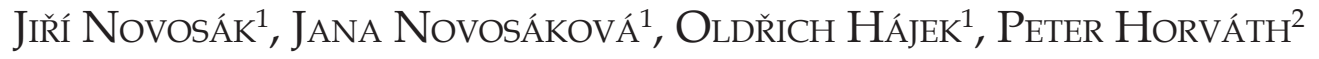 \\ ${ }^{1}$ Department of Regional Development, Public Sector Administration and Law, Faculty of Management \\ and Economics, Tomas Bata University in Zlin, Czech Republic \\ ${ }^{2}$ Department of Public Policy and Public Administration, Faculty of Social Sciences, University of St. Cyril \\ and Methodius in Trnava, Slovakia
}

Manuscript received: December 08, 2016

Revised version: August 23, 2017

\begin{abstract}
Novosák J., Novosáková J., HájeK O., Horváth P., 2017. Regional disparities, absorption capacity and Structural Fund payments: A case study of the Czech Republic. Quaestiones Geograpicae 36(4), Bogucki Wydawnictwo Naukowe, Poznań, pp. 81-92, 7 tables, 1 fig.

ABSTRACT: The intention of this paper is to provide empirical evidence on how the factors of socio-economic disadvantage and absorption capacity influence the spatial distribution of Structural Fund (SF) payments among the Czech Republic's micro-regions during the 2007-2013 programming period. The empirical results indicate that agglomeration economies, innovation and entrepreneurship are associated with higher SF absorption capacity and higher SF payments, challenging the tendency for socio-economically disadvantaged regions to converge. SF absorption capacity measured especially by the number of project applications submitted for SF financing and by the average SF budget per project application, is a crucial concept in order to understand the relationship between within-country regional disparities and SF interventions.
\end{abstract}

KEY WORDS: regional disparities, convergence, absorption capacity, Structural Funds, Czech Republic

Corresponding author: Jiři Novosák, Department of Regional Development, Public Sector Administration and Law, Faculty of Management and Economics, Tomas Bata University in Zlin, Mostni 5139, 76001 Zlin, Czech Republic; e-mail: novosak@fame. $u t b . c z$

\section{Introduction}

Regional inequalities are certainly an important current research topic. This is substantiated by the facts that: (1) inequality is a fundamental feature of regional development (Hudson 2007), and (2) severe regional inequalities may threaten social and territorial cohesion (Ezcurra 2009). Moreover, regional inequalities are an issue of concern at various spatial levels, including both between-country and within-country inequalities. This holds true also for the post-communist
CEE countries where within-country regional inequalities have increased substantially after the fall of communism (Tatar 2010; Artelaris, Kallioras, Petrakos 2010; Smetkowski 2013).

The accession of CEE countries to the European Union in 2004 opened the door to regional development support from EU Structural Funds (hereafter referred to as SF). In this regard, Jurevičienè and Pileckaitè (2013), Tatar (2010), Iatu and Alupului (2011) point out the importance of SF as a lever for regional development in the CEE countries. The amount of SF payments received 
and the eligibility of almost all CEE regions for the Convergence objective are highly important. Consequently, SF plays a crucial role in dealing with increasing within-country regional inequalities in the CEE countries (Tatar 2010; Novosák et al. 2015).

SF payments used as a measure to compensate for regional structural disadvantages is one way of dealing with the associations between SF and within-country regional inequalities (Crescenzi 2009; Modranka 2015). With this way of thinking, SF payments ought to be channelled into socio-economically disadvantaged regions, provoking the regional convergence-divergence debate from a theoretical point of view. The factors of regional development are of crucial importance in this regard. There are, moreover, other factors influencing the spatial distribution of SF payments, including SF absorption capacity (Zaman, Georgescu 2009; Jurevičienè, Pileckaitè 2013), political interests (Dellmuth, Stoffel 2012; Schraff 2014), and spatial interactions (Camaioni et al. 2013; Crescenzi 2009).

This paper is based on the regional convergence-divergence debate, searching for the important factors of regional development to explain the spatial pattern of SF payments. To paraphrase Blažek and Macešková (2010), the main research question is about which regions SF payments are channelled into - "rich" or "poor"? Hence, the aim of this paper is to expound the data on the question asked, and to examine socio-economic disadvantages and how they influence the spatial distribution of SF payments among the Czech Republic's micro-regions in the programming period from 2007 to 2013. Researching the influence of particular factors is one of the goals of this paper. We hypothesise that more SF are allocated to socio-economically disadvantaged regions (convergence). Moreover, the associations between SF payments, SF absorption capacity and the socio-economic disadvantages of micro-regions are explored.

The paper is structured as follows: the second section provides a theoretical framework. The third section presents data and research methods. The fourth section summarises results which are then discussed in the fifth section. The last section concludes the paper.

\section{Theoretical framework}

The regional convergence-divergence debate has been framed in numerous theoretical perspectives. Two questions are of particular interest here, i.e. whether convergence or divergence processes prevail and what the factors of existing regional disparities are.

The neoclassical growth model assumes that convergence will occur due to decreasing returns to scale (Fischer, Stirböck 2006; Barro, Sala-I-Martin 1992) and also due to mobility of the factors of production (Martin, Sanz 2003; Puga 2002). However, the literature on this model shows that empirical results are far from convincing (Boldrin, Canova 2001; PugicerverPeňalver 2007). Hence, Churski (2005), and Baláž (2007) point out a strong core-periphery pattern of regional development in CEE countries with a strengthening position of core regions. This pattern is explained by the increasing importance of agglomeration economies (Geppert, Stephan 2008), and by a spatially uneven distribution of human capital (Baláž 2007), innovations (Simmie, Carpenter 2008), and infrastructure (Baláž 2007).

The core-periphery pattern of regional development is also at the heart of other theoretical perspectives. The growth pole theory claims that the intensity of development varies significantly across regions, resulting in persistent regional disparities. The importance of large firms, infrastructure and innovations as the factors of development and their concentration in core regions are emphasised in this theory (Parr 1999). The core-periphery pattern of regional development is also thoroughly discussed in new economic geography models (Fujita, Krugman 2004). Whether convergence or divergence tendencies prevail depends on the relative strength of centripetal (agglomeration economies) and centrifugal (agglomeration diseconomies) forces (Krugman 1991; Puga 2002). Increasing returns are of crucial importance.

Several theories of regional development have emerged as a response to structural change in the economy since the 1970s. The theories include industrial districts (Becattini 1978), innovative milieux (Maillat 1998), clusters (Porter 1990), and regional innovation systems (Tödtling, Trippl 2005). Entrepreneurship and SME development, innovations, and also human and social capital 
are frequently mentioned attributes of regional development in these theories. Moreover, lagging regions are offered a way to lay the foundations of development based on their endogenous potential (Moulaert, Mehmmod 2010). Thus, the regional convergence-divergence debate has no single correct answer.

The regional convergence-divergence debate provides the field for considering regional policy. Two main objectives of regional policy may be distinguished: (a) equity, and (b) efficiency (Fratesi 2008; Boldrin, Canova 2001). Originally, the two objectives were regarded complementary to each other, as suggested by the neoclassical growth model (Fratesi 2008) and this policy should support the development of lagging regions (Boldrin, Canova 2001; Enflo, Hjerstrand 2009). However, this line of thought has been questioned by theories that emphasise the importance of increasing returns and agglomeration economies. The equity and efficiency objectives may conflict in this case (Kaufmann, Wagner 2005; De Propris 2007) or even spatial concentration may lead to reduction in regional disparities (Puga 2002).

In the empirical analyses of the relationship between regional policy and regional disparities, two strands of research may be observed. Firstly, a number of studies have explained the impact of regional policy funds on regional convergence, providing mixed results (Esposti, Bussoletti 2008; Boldrin, Canova 2001; Lolos 2009). The second strand of research has, on the contrary, focused on the factors that explain the pattern of regional policy funds allocation (Crescenzi, De Fillipis, Pierangeli 2015; Novosák et al. 2015; Camaioni et al. 2013). The main idea here is that regional policy funds are expected to compensate for the structural disadvantages of regions to achieve regional convergence (Crescenzi 2009). However, this relationship was true especially for ex-ante evaluations with the predetermined rules of the allocation of regional policy funds that favoured lagging regions (Lambrinidis, Psycharis, Rovolis 2005; Lolos 2009). The research based on the competition of regions for these payments, typically done at lower spatial levels, did not indicate an allocation of higher regional policy funds in lagging regions (Blažek, Macešková 2010; Camaioni et al. 2013; Novosák et al. 2015; Czyż, Hauke 2011). Several authors in this respect speak about the lower absorption capacity of these regions, particularly in the case of more progressive thematic areas (Kaufmann, Wagner 2005; Novosák et al. 2017).

Several complementary perspectives of the absorption capacity of regional policy funds were suggested in the literature. The most common definition is that of the capacity of member states to spend regional policy funds effectively and efficiently (Milio 2007; Zaman, Georgescu 2009; Jurevičienė, Pileckaitè 2013; Pawlicz 2014; Iatu, Alupului 2011), capturing both quantitative and qualitative dimensions of the concept (Duran 2014). Jurevičienė and Pileckaitè (2013), Popescu (2015), Tatar (2010), and Cace et al. (2009) provide another perspective on the issue, distinguishing between the demand and supply sides of the absorption capacity of regional policy funds. Institutional aspects are widely regarded as associated with the supply side of regional policy funds absorption capacity (Cace et al. 2009; Modranka 2015). The demand side is, on the contrary, associated with the capacity to submit acceptable projects for regional policy programmes (Pawlicz 2014; Jurevičienè, Pileckaitè 2013).

The demand side of absorption capacity is crucial in explaining the within-country regional disparities in the allocation of regional policy funds. In this regard, bottlenecks, constraints in the development of skills and expertise, the lack of co-financing funds, problems encountered in searching for project partners, and relatively weak lobbying power may all put lagging regions in a disadvantaged position concerning their SF absorption capacity (Tosun 2014; Jaliu, Radulescu 2013; Zaman, Georgescu 2009; Popescu 2015; Modranka 2015; Iatu, Alupului 2011; Tatar 2010; Jurevičienè, Pileckaitè 2013; Cace et al. 2009). This disadvantaged position exists despite the strong need for SF intervention in these regions (Popescu 2015; Jurevičienè, Pileckaitè 2013; Jaliu, Radulescu 2013).

Regardless of the extensive theoretical literature, there have been few empirical studies on factors that explain the allocation of regional policy funds while considering the influence of the absorption capacity concept. This paper tries to fill, at least partially, that information void and tries to examine how factors of development influence the spatial distribution of SF payments 
among the Czech Republic's micro-regions in the programming period from 2007-2013, while also considering the influence of the absorption capacity concept.

\section{Methodology}

The methodology of this paper is derived from all project applications that were submitted for financing under the Convergence objective in the Czech Republic (in the 2007-2013 programming period) until June 2016. Due to the interest in micro-regional absorption capacity, the project applications submitted by central authorities were excluded from the analyses. However, almost 120,000 project applications were evaluated. The sources of information were official data published by the Ministry of Regional Development of the Czech Republic (hereafter referred to as the MRDCR), also by the Ministry of Industry and Trade of the Czech Republic (hereafter referred to as the MITCR), and also by the Ministry of Labour and Social Affairs of the Czech Republic (hereafter referred to as the MLSACR).

Three attributes of project applications were crucial for defining both the dependent and explanatory variables: (a) the SF requested/allocated for each project application; (b) the decision of approving each project application; and (c) the geographic locations for which each project application was intended. Note that the variables referred to 205 micro-regions that corresponded to the administrative areas between level LAU 1 and LAU 2, and also that Prague was omitted from further analysis because it was ineligible for the Convergence objective. Then, the dependent variable was defined as SF payments (in CZK) allocated in a micro-region for every inhabitant of its territory (hereafter referred to as $\mathrm{SF}_{-}$ PAYMENT). The variable was log-transformed to reduce skewing the data.

The explanatory variables were chosen by using the theoretical framework presented in this paper. Firstly, the explanatory variables of socio-economic disadvantages in micro-regions were defined using the first three principal components of principal component analysis (PCA) on eight indicators (Table 1 ). The indicators relate to economic, social and environmental pillars of sustainable development and refer, as close as possible, to the year 2007 in order to avoid the endogeneity problem (Crescenzi 2009 for this approach). Note that when appropriate, log-transformation was used to improve normality of the indicators, for the purposes intended. When establishing the number of factors, Kaiser's criterion was applied, retaining only those factors with an eigenvalue of 1 or greater.

Table 2 shows the rotated component matrix obtained by using the varimax rotation method. The principal components were interpreted as relating to three dimensions of socio-economic disadvantages of micro-regions:

1. The first principal component reflects the conditions of an innovative and entrepreneurial

Table 1. The socio-economic disadvantages of micro-regions - indicators.

\begin{tabular}{|l|l|c|}
\hline \multicolumn{1}{|c|}{ Indicators } & \multicolumn{1}{|c|}{ Description } & Year; source \\
\hline Air quality & $\begin{array}{l}\text { Emission values of nineteen air pollutants per square kilometre; log-trans- } \\
\text { formed }\end{array}$ & $2007 ;$ CHMI \\
\hline Ecological stability & $\begin{array}{l}\text { Ratio between environmentally stable and environmentally unstable land-use } \\
\text { categories }\end{array}$ & 2007 ; CSO \\
\hline Entrepreneurship & Share of employers and own-account workers in the total workforce & $\begin{array}{c}\text { Mean of 2001 } \\
\text { and 2011; CSO }\end{array}$ \\
\hline $\begin{array}{l}\text { Environmental } \\
\text { infrastructure }\end{array}$ & Share of population with access to sewerage infrastructure & $\begin{array}{c}\text { Mean of 2001 } \\
\text { and 2011; CSO }\end{array}$ \\
\hline Human capital & Share of tertiary educated people in the population above the age of 15 & $\begin{array}{c}\text { Mean of 2001 } \\
\text { and 2011; CSO }\end{array}$ \\
\hline Innovations & $\begin{array}{l}\text { Number of patent applications and utility models per 100.000 inhabitants; } \\
\text { log-transformed }\end{array}$ & $\begin{array}{c}\text { Mean of 2002 } \\
\text { to 2007; IPOCR }\end{array}$ \\
\hline Population density & Number of inhabitants per square kilometre; log-transformed & 2007 CSO \\
\hline Unemployment & Share of unemployed people in the population aged 15-64 years & $\begin{array}{c}\text { Mean of 2005 } \\
\text { to 2007; CSO }\end{array}$ \\
\hline
\end{tabular}

Note: Czech Hydrometeorological Institute (hereafter referred to as CHMI); Czech Statistical Office (hereafter referred to as CSO); Industrial Property Office of the Czech Republic (hereafter referred to as IPOCR). 
Table 2. PCA - Rotated component matrix.

\begin{tabular}{|l|c|c|c|}
\hline \multicolumn{1}{|c|}{ Indicators } & Component 1 & Component 2 & Component 3 \\
\hline Air quality & -0.175 & 0.489 & 0.674 \\
\hline Ecological stability & -0.088 & 0.076 & -0.891 \\
\hline Entrepreneurship & 0.778 & -0.153 & -0.222 \\
\hline Environmental infrastructure & -0.095 & 0.719 & -0.122 \\
\hline Human capital & 0.669 & 0.575 & 0.201 \\
\hline Innovations & 0.647 & 0.355 & 0.140 \\
\hline Population density & 0.031 & 0.839 & 0.310 \\
\hline Unemployment & -0.819 & 0.336 & -0.028 \\
\hline Explained variance & $31.1 \%$ & $26.9 \%$ & $13.4 \%$ \\
\hline Initial eigenvalues & 2.489 & 2.154 & 1.073 \\
\hline
\end{tabular}

Source: compiled by the authors; data from the CHMI, the CSO and the IPOCR.

economy (hereafter referred to as INNOV ENTREP), as indicated by the strong associations between indicators of entrepreneurship, human capital, innovations and unemployment. Higher values mean a more innovative and entrepreneurial economy.

2. The second principal component relates to agglomeration economies and diseconomies (hereafter referred to as AGGLOM), as indicated by the strong associations between indicators of population density, environmental infrastructure, human capital and air quality. Higher values mean more intense agglomeration effects.

3. The third principal component is strongly linked to the indicators of environmental quality (hereafter referred to as ENVI_QUAL) - ecological stability and air quality. Higher values mean lower environmental quality.

Secondly, variables relating to SF absorption capacity were introduced. The distinction was made between: (1) the demand side of SF absorption capacity; and (2) the supply side of SF absorption capacity. Referring to the theoretical framework, the demand side of SF absorption capacity is understood as the capacity to submit acceptable projects for SF programmes (Pawlicz 2014; Jurevičienè, Pileckaitè 2013; Tatar 2010; Popescu 2015). There were three pillars identified on the demand side of SF absorption capacity that influence the spatial distribution of SF payments:

- the number of project applications submitted for SF financing,

- the amount of SF requested for project applications,
- the share of project applications supported by SF.

Three variables were defined relating to the demand side of SF absorption capacity. The first variable (hereafter referred to as PROJ_NUMBER) is the number of all project applications submitted for SF financing per 10,000 inhabitants of a micro-region, and this was log-transformed to improve the normality of distribution. The second variable (hereafter referred to as PROJ_SIZE) relates to the average $\mathrm{SF}$ budget requested per project application in a micro-region, and it was log-transformed to improve the normality of distribution. The third variable (hereafter referred to as APPROV_RATE) is the success rate of project applications submitted for SF financing in a micro-region. The sources of information were the official data published by the MRDCR, by the MITCR, and also by the MLSACR.

The Czech Republic allocated SF payments in the 2007-2013 programming period using both national thematic operational programmes and also regional operational programmes (hereafter referred to as ROPs). Albeit ROPs accounted for only a small share of the total SF allocation, institutional differences between them might have influenced spatial distribution of SF payments. These institutional differences also include the problem of "rent-seeking" behaviour that was noticed, especially in the case of ROPs in the south-west and north-west. The supply side of SF absorption capacity was put into operation by using seven dummy variables indicating whether a micro-region belonged to a NUTS 2 region, or not. The north-east (NUTS 2) was chosen as a reference category because it has the highest 
number of observations and is closest to the mean value of the dependent variable.

Finally, the importance of political interests was shown by using a dummy variable. This was unity if government parties won more than 50\% of votes in Parliamentary elections for the micro-region in 2006 and 2010 (hereafter referred to as GOVERNMENT). The source of information was the CSO.

Concerning methodology, data was analysed using descriptive and inferential statistics, including the calculation of Moran's I - a measure of spatial autocorrelation between adjacent observations. Multiple linear regression modelling was also carried out to address the research goal. The cross-section models were in this general form:

$y_{i}=a_{0}+\sum_{j=1}^{J} a_{j} S E_{\text {DISADV }_{j i}} \sum_{l=1}^{L} \beta_{l} S F_{A B S O R P T I O N}^{l i}+\sum_{m=1}^{M} \gamma_{m} P O L_{m i}+u_{i}$

whereby $y_{i}$ is SF_PAYMENT in a micro-region $i$; $S E_{D_{I S A D V} i}$ is a variable $j$ relating to the three components of socio-economic disadvantage in a micro-region $i ; S E_{A B S O R P T I O N_{i l}}$ is a variable $l$ relating to SF absorption capacity in a micro-region $i$; $P O L_{m i}$ is a variable $m$ concerning political interests in a micro-region $i ; a_{i^{\prime}} \beta_{l}$ and $\gamma_{m}$ are regression coefficients; and $u_{i}$ is the error term. The models were estimated by OLS (ordinary least squares) with heteroscedasticity-robust standard errors. Moreover, the traditional regression assumptions were tested using the Kolmogorov-Smirnov and Shapiro-Wilk tests for normality, by using the variance inflation factor (VIF) for multi-collinearity and also Moran's I for spatial autocorrelation. The statistics confirmed that the regression assumptions were not seriously violated.

\section{Empirical results}

The spatial distribution of SF payments per inhabitant is shown in Fig. 1, suggesting a mosaic spatial pattern. Despite the existence of some clusters of low and high values, Moran's I is statistically significant only at the 0.05 significance level. The same figure also illustrates that SF payments per inhabitant tend to follow

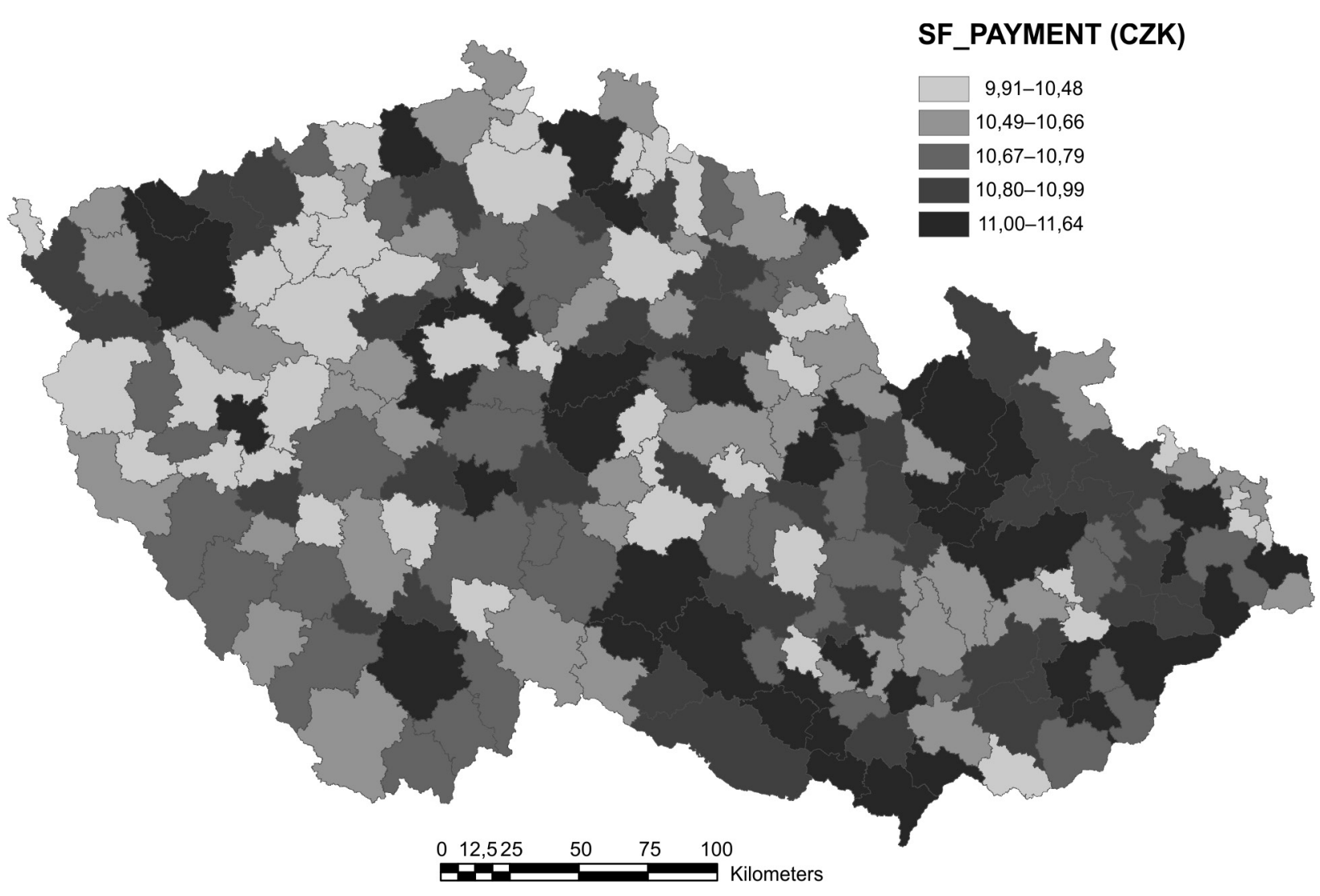

Fig. 1.SF_PAYMENT - micro-regions.

Source: compiled by the authors; data from the MRDCR, the MITCR, the MLSACR, and the CSO. 
Table 3.SF_PAYMENT - NUTS 2 regions.

\begin{tabular}{|l|c|c|c|c|c|c|c|}
\hline $\begin{array}{l}\text { NUTS 2 } \\
\text { REGION }\end{array}$ & CB & SW & NW & NE & SE & CM & MS \\
\hline $\begin{array}{l}\text { SF_PAY- } \\
\text { MENT }\end{array}$ & 10.71 & 10.61 & 10.64 & 10.71 & 10.83 & 10.89 & 10.76 \\
\hline
\end{tabular}

Note: CB - Central Bohemia; SW - South West; NW

- North West; NE - North East; SE - South East; CM -

Central Moravia; and MS - Moravia-Silesia.

Source: compiled by the authors; data from the MRDCR, the MITCR, the MLSACR, and the CSO.

a core-periphery pattern and the east-west gradient, indicating higher values in core micro-regions of large agglomerations and also higher values in the eastern Czech Republic (see also Table 3 for the means of SF payments per inhabitant in the Czech NUTS 2 regions). The position of Prague is weakened by its omission from the Convergence objective; nevertheless, the micro-regions nearby at least partially fill the gap.

These findings are of importance in considering the associations between SF payments and within-country micro-regional inequalities in the Czech Republic. Hence, the core micro-regions play a crucial role in receiving SF payments, further reinforcing their conditions for economic development. However, the clusters of high SF payments per inhabitant in southern and north-western Moravia indicate that peripheral micro-regions are also important SF beneficiaries. Moreover, the literature points out a higher level of socio-economic performance in the western part of CEE countries, while western micro-regions receive rather low $\mathrm{SF}$ payments (Czyż, Hauke 2011), including the Czech Republic (Blažek, Netrdová 2012). Finally, Blažek and Netrdová (2012), Novák and Netrdová
(2011) note the socio-economic disadvantages of the old industrial micro-regions located in the north-western and north-eastern parts of the Czech Republic. In this regard, SF payments per inhabitant are low in several micro-regions. Overall, a complex mosaic of relations between SF payments and regional disparities of Czech micro-regions is revealed.

Table 4 provides initial insights into understanding the associations of SF payments and SF absorption capacity on one hand, and on the other hand, the factors of socio-economic disadvantages. The most significant associations are found in relation to agglomeration effects which are positively associated with the project size, while also negatively associated with the number of submitted project applications and their success rate. The variables of innovative and entrepreneurial economies and of environmental quality both positively and significantly relate to the number of submitted project applications. Moreover, the variable relating to environmental quality is negatively and significantly associated with the success rate of project applications. The other associations are not statistically significant, including all the associations between SF payments per inhabitant and the factors of socio-economic disadvantages.

Table 5 adds information concerning Moran's I - a measure of spatial autocorrelation between adjacent observations - for variables relating to SF payments and socio-economic disadvantages of micro-regions. All the values are positive and statistically significant at least at the 0.05 significance level. The results obtained, therefore, indicate the presence of positive spatial dependence in

Table 4. Pearson correlation coefficients.

\begin{tabular}{|l|c|c|c|c|}
\hline \multicolumn{1}{|c|}{ Variables } & SF_PAYMENT & PROJ_NUMBER & PROJ_SIZE & APPROV_RATE \\
\hline INNOV_ENTREP & 0.133 & $0.151^{*}$ & -0.027 & -0.089 \\
\hline AGGLOM & 0.119 & $-0.287^{\text {** }}$ & $0.373^{* *}$ & $-0.415^{* *}$ \\
\hline ENVI_QUAL & -0.010 & $0.148^{*}$ & 0.031 & $-0.169^{*}$ \\
\hline
\end{tabular}

"statistically significant at the 0.05 significance level; " statistically significant at the 0.01 significance level. Source: compiled by the authors; data from the MRDCR, the MITCR, the MLSACR, the CHMI, the CSO, and the IPOCR.

Table 5. Moran's I.

\begin{tabular}{|c|c|c|c|c|}
\hline Variables & SF_PAYMENT & INNOV_ENTREP & AGGLOM & ENVI_QUAL \\
\hline Moran's I & $0.110^{*}$ & $0.487^{* *}$ & $0.356^{* *}$ & $0.522^{* *}$ \\
\hline
\end{tabular}

"statistically significant at the 0.05 significance level; " statistically significant at the 0.01 significance level. Source: compiled by the authors; data from the MRDCR, the MITCR, the MLSACR, and the CSO. 
Table 6. Pearson correlation coefficients

\begin{tabular}{|l|c|c|c|c|}
\hline & SF_PAYMENT & PROJ_NUMBER & PROJ_SIZE & APPROV_RATE \\
\hline SF_PAYMENT & - & $0.487^{*+}$ & $0.470^{*+*}$ & -0.083 \\
\hline PROJ_NUMBER & $0.487^{+*}$ & - & $-0.329^{*+}$ & -0.115 \\
\hline PROJ_SIZE & $0.470^{*+*}$ & $-0.329^{* *}$ & - & $-0.340^{* *}$ \\
\hline APPROV_RATE & -0.031 & -0.115 & $-0.340^{*+}$ & - \\
\hline
\end{tabular}

** statistically significant at the 0.01 significance level.

Source: compiled by the authors; data from the MRDCR, the MITCR, the MLSACR, and the CSO.

SF payments across the micro-regions. However, socio-economic disadvantages of micro-regions indicate a much higher regional concentration, and SF payments do not fully compensate for socio-economic disadvantage of micro-regions.

Table 6 gives information about the micro-regional associations between the spatial distribution of SF payments and SF absorption capacity, using Pearson bivariate correlations. The results reveal statistically significant associations between a SF payment per inhabitant and two variables of SF absorption capacity: (a) the number of submitted project applications; and (b) the project size. The indication of associations is positive, as expected. The associations between the variables relating to a SF payment per inhabitant and to the success rate of project applications are, on the contrary, statistically insignificant. Two other correlations in this table are statistically significant. Firstly, the number of submitted project applications is negatively associated with the project size. Hence, there is some trade-off between these two variables of SF absorption capacity. Secondly, the project size is negatively associated with the variable relating to the success rate of project applications. Overall, two alternative strategies seem to be operating here. The first strategy prefers numerous small-scale project applications, while the second prefers a smaller number of project applications with higher budget requests. Note that the latter strategy has a lower project approval rate.

\section{Discussion}

In the preceding section there were several interesting associations made between the spatial distribution of SF payments, socio-economic disadvantages of micro-regions and SF absorption capacity. This section verifies findings by estimating four cross-section regression models (see
Table 7 for regression model estimates) and these are further discussed in the convergence-divergence context. SF payments per inhabitant are the dependent variable in each of the models.

The preceding section showed weak associations between SF payments per inhabitant and socio-economic disadvantages of micro-regions. These were more spatially concentrated than the SF allocation (Crescenzi 2009; Novosák et al. 2015 for the same finding). Similarly, the correlations between the variables of socio-economic disadvantages and SF payments per inhabitant are rather weak, further indicating that the SF allocation has a disperse nature across micro-regions (Blažek, Macešková 2010 for a similar finding). Consequently, the contribution of SF payments to the convergence of micro-regions is ambiguous. Moreover, it seems less SF payments were allocated in socio-economically disadvantaged micro-regions. This is because of core-periphery patterns of the SF allocation and the positive signs of correlations between the variables relating on one hand to agglomeration effects and innovative and entrepreneurial economy, and on the other hand, to SF payments per inhabitant.

These findings are supported by the estimates of our first regression model that includes only the variables relating to socio-economic disadvantages of micro-regions. Firstly, the model explains only a minor portion of the variation in a SF payment per inhabitant, confirming the weak associations of the variables. Moreover, two explanatory variables are positively and, at the 0.05 significance level, significantly associated with the dependent variable: (a) the innovative and entrepreneurial economy; and (b) the agglomeration effects. It is noteworthy that recent theories of regional development emphasise the importance of just these factors of regional development. Our findings suggest that the micro-regions endowed with these factors of development also receive higher SF payments 
Table 7. Regression model estimates.

\begin{tabular}{|l|c|c|c|c|}
\hline & Model 1 & Model 2 & Model 3 & Model 4 \\
\hline Constant & $10.73^{* *}(0.02)$ & $6.57^{* *}(0.48)$ & $-3.86^{* *}(1.26)$ & $11.57^{* *}(0.31)$ \\
\hline INNOV_ENTREP & $0.06^{*}(0.02)$ & $0.03(0.03)$ & $0.08^{* *}(0.03)$ & $0.07(0.03)$ \\
\hline AGGLOM & $0.06^{*}(0.03)$ & $0.10^{* *}(0.02)$ & $-0.07^{* *}(0.02)$ & $-0.01(0.03)$ \\
\hline ENVI_QUAL & $0.01(0.02)$ & $0.05^{*}(0.02)$ & $-0.03^{*}(0.02)$ & $-0.01(0.02)$ \\
\hline PROJ_NUMBER & - & $0.89^{* * *}(0.10)$ & - & - \\
\hline PROJ_SIZE & - & - & $0.91^{* *}(0.08)$ & - \\
\hline APPROV_RATE & - & - & - & $-0.01^{* *}(0.00)$ \\
\hline CB & - & $-0.02(0.07)$ & $-0.07(0.06)$ & $-0.08(0.08)$ \\
\hline CM & - & $-0.14(0.08)$ & $0.42^{* *}(0.06)$ & $0.17^{*}(0.08)$ \\
\hline MS & - & $-0.09(0.09)$ & $0.26^{* *}(0.07)$ & $0.11(0.10)$ \\
\hline NW & - & $0.03(0.08)$ & $-0.12(0.08)$ & $-0.07(0.11)$ \\
\hline SE & - & $-0.09(0.08)$ & $0.28^{* *}(0.06)$ & $0.14^{* *}(0.08)$ \\
\hline SW & - & $-0.21^{* *}(0.07)$ & $-0.04(0.06)$ & $-0.21(0.09)$ \\
\hline GOVERNMENT & - & $-0.03(0.06)$ & $0.00(0.06)$ & $-0.03(0.08)$ \\
\hline Adjusted R & - & 0.35 & 0.49 & 0.12 \\
\hline N & 0.05 & 205 & 205 & 205 \\
\hline Moran's I (OLS) & 205 & $2.163^{*}$ & $2.356^{*}$ & 1.443 \\
\hline
\end{tabular}

"statistically significant at the 0.05 significance level; the heteroscedasticity robust standard errors in parentheses; * statistically significant at the 0.01 significance level.

Source: compiled by the authors; data from the MRDCR, the MITCR, the MLSACR, the CHMI, the CSO, the IPOCR.

(Klímová, Žítek 2015; Kaufmann, Wagner 2005 for similar findings relating to innovations), again limiting the balancing effect of the SF allocation. The results remain stable also after checking the presence of spatial dependence in data through a spatial error model estimate (Anselin et al. 1996).

The question is, 'Why do socio-economically disadvantaged micro-regions lag behind in SF payments?' Is this due to: (a) the number of submitted project applications; or (b) the project size; or (c) the success rate of project applications? The remaining three regression models provide some interesting insights into these questions. The empirical strategy is that always one of the three variables relating to absorption capacity - and also other control variables - are added into the regression models. The significance of variables is subsequently discussed.

The project size is the most significant variable for explaining the variation in SF payments, as shown by adjusted $\mathrm{R}^{2}$ and by estimated coefficients and standard errors. Generally, the project size is closely associated with agglomeration effects that remain significant after controlling for the influence of the project size, but the variable changes its sign to negative. Hence, the core-periphery pattern of the SF allocation is created especially by the capacity of large agglomerations to prepare and submit large projects and this agrees with claims made by a number of authors (Iatu, Alupului 2011; Modranka 2015; Tatar 2010) stressing the problems of peripheral regions to find project opportunities in several, notably progressive areas (Kaufmann, Wagner 2005; Václavík 2015 for innovations). It is noteworthy that the same associations are also observed for the variable relating to environmental quality. Hence, less of the larger projects are realised in environmentally disadvantaged micro-regions.

Another distinct relationship is observed between the number of submitted project applications and the variable relating to the innovative and entrepreneurial economy. Hence, more projects are prepared and submitted in micro-regions that are characterised by a strong innovative and entrepreneurial climate. This may be perceived as a supplement to the numerous endogenous theories of regional development. Once a strong innovative and entrepreneurial climate of a region has been created, this region has a greater capacity to successfully compete for SF payments. The contrary is true for the regions lacking agglomeration economies, innovativeness and a strong entrepreneurial climate (Jurevičienè, Pileckaitė 2013; Modranka 2015; Popescu 2015). Hence, it is desirable to mobilise endogenous potential in these regions, in accordance with the theories of regional development. SF payments may support 
such a mobilisation; however, the use of instruments that are territorially targeted (e.g. ITI and LAGs) may be beneficial to reduce the problem of low absorption capacity for these regions (Lošták, Hudečková 2010). Note that the old industrial micro-regions located in the north-western and north-eastern parts of the Czech Republic are special regions lacking innovativeness and lacking a strong entrepreneurial climate, however they have strong agglomeration effects (Blažek, Netrdová 2012; Novák, Netrdová 2011).

The success rate of project applications is the least significant predictor of SF payments per inhabitant when considering the three variables relating to the demand side of the absorption capacity concept. This is suggested by the low adjusted $\mathrm{R}^{2}$ and by estimated coefficients and standard errors. The negative sign of the variable is remarkable. Hence, a higher success rate of the project application in a micro-region is associated with a lower average SF payment per inhabitant, indicating some balancing effect of the approval process. Nevertheless, this effect is weaker than the influence of the variables relating to the project size and the number of submitted project applications.

Overall, socio-economically disadvantaged regions do not receive more SF payments per inhabitant due to their lower capacity: (a) to prepare and submit a large number of projects; and (b) to prepare and submit financially demanding projects. Consequently, the traditional goal to support lagging regions, as suggested, e.g. by the neoclassical growth model (Barro, Sala-IMartin 1992), is disputed. However, more recent theoretical approaches to regional development describe the mechanism that supporting core regions contribute to convergence (Puga 2002). In our opinion, this mechanism may be of great importance at the micro-regional level.

\section{Conclusions}

The aim of this paper is to examine the influence of various socio-economic disadvantages on the spatial distribution of SF payments among the Czech Republic's micro-regions in the programming period from 2007 to 2013. Moreover, this influence was discussed in the context of the convergence-divergence debate. The three main factors of socio-economic disadvantages extracted using PCA were: (a) an innovative and entrepreneurial economy, (b) agglomeration effects, and (c) environmental quality. Note that the former two factors are cornerstone principles of modern theories of regional development, confirming the appropriateness of their choice. Moreover, the associations between SF payments, SF absorption capacity and the socio-economic disadvantages of micro-regions were expounded.

Concerning the issue of having an innovative and entrepreneurial economy, its positive influence on SF payments was identified. This influence was especially caused by a greater number of projects prepared and submitted for SF co-financing in the micro-regions characterised by a strong innovative and entrepreneurial environment (Kaufmann, Wagner 2005; Klímová, Žítek 2015; Novosák et al. 2017 for similar conclusions). It seems that stimulating an innovative and entrepreneurial environment is essential not only for regional development (Becattini 1978; Maillat 1998; Tödtling, Trippl 2005), but also for SF absorption capacity. Clearly, SF may be used to stimulate innovative and entrepreneurial environments of lagging regions; however, implementing some territorially targeted instruments (e.g. ITI and LAGs) may be fruitful in solving the problem of their lower absorption capacity.

Concerning the factor of agglomeration effects - its positive influence on SF payments was also confirmed. However, in this case, the positive influence is associated with the capacity to prepare and submit financially demanding projects in micro-regions that have strong agglomeration economies (Tatar 2010; Iatu, Alupului 2011; Modranka 2015 for the problems of lagging regions to find project opportunities in some thematic areas). The factor of environmental quality was not found to be statistically significant in explaining the micro-regional variation in SF payments.

In conclusion, the results regarding SF payments as a compensation for socio-economical disadvantages in Czech micro-regions are ambiguous. Consequently, the convergence-divergence debate does not provide a straightforward answer. Rather, complex theoretical assumptions must be considered. These considerations also include the recent theoretical models showing that supporting core regions may paradoxically lead to a reduction of regional disparities (Puga 2002). The empirical results also suggest that the demand 
side of SF absorption capacity is vitally important in explaining the spatial distribution of SF payments among the Czech Republic's micro-regions (Jurevičienè, Pileckaitè 2013; Popescu 2015; Tatar 2010; Cace et al. 2009 for the importance of this concept). The number of applications submitted for SF financing, and the average SF budget per project application were the strongest predictors of the spatial distribution of SF payments.

Some political implications can be drawn from the results. Firstly, SF absorption capacity is crucial for understanding the relationship between within-country regional disparities and SF interventions. Strengthening the demand side of SF absorption capacity in "cold desert" is a prerequisite for higher SF payments. Secondly, the relationship between within-country regional disparities and the spatial distribution of SF payments is quite ambiguous. Spatial concentration of SF payments is rather weak in the Czech Republic. Moreover, agglomeration economies, innovation and entrepreneurship seem to be associated with greater SF absorption capacity and higher SF payments, further challenging the weaker position of socio-economically disadvantaged regions. A slightly adjusted approach may be beneficial in order to conceptualise the associations between SF payments, SF absorption capacity and socio-economic disadvantages of regions, and this adjusted approach could then tackle the problem of ever increasing within-country regional disparities.

\section{Acknowledgements}

The authors are thankful for grant no. 16-22141S provided by the Czech Science Foundation for the financial support needed to carry out this research. Data provision from the Czech Statistical Office (the Zlín Office) is kindly acknowledged.

\section{References}

Anselin L., Bera A.K., Florax R.J., Yoon M.J., 1996. Simple diagnostic tests for spatial dependence. Regional Science and Urban Economics 26(1): 77-104.

Artelaris P., Kallioras D., Petrakos G., 2010. Regional inequalities and convergence clubs in the European Union new member-states. Eastern Journal of European Studies 1(1): 113-133.

Baláž V., 2007. Regional polarization under transition: The case of Slovakia. European Planning Studies 15(5): 587-602.
Barro R.J., Sala-I-Martin X., 1992. Convergence. Journal of Political Economy 100(2): 223-251.

Becattini G., 1978. The development of light industry in Tuscany. Economic Notes 3(2): 107-122.

Blažek J., Macešková M., 2010. Regional analysis of public capital expenditure: To which regions are public capital expenditure channelled - to "rich" or to "poor" ones? Regional Studies 44(6): 679-696.

Blažek J., Netrdová P., 2012. Aktuální tendence lokální diferenciace vybraných socioekonomických jevů v Česku: směřuje vývoj $\mathrm{k}$ větší mozaikovosti prostorového uspořádání? (Contemporary tendencies of the development of spatial pattern on the local level in Czechia: Towards higher fragmentation of the spatial pattern?). Geografie 117(3): 266-288.

Boldrin M., Canova F., 2001. Inequality and convergence in Europe's regions: Reconsidering European regional policies. Economic Policy 16(32): 207-253.

Cace C., Cace S., Iova C., Nicolaescu V., 2009. Absorption capacity of the structural funds. Integrating perspectives. Revista de Cercetare şi Intervenție Socială 27: 7-28.

Camaioni B., Esposti R., Lobianco A., Pagliacci F., Sotte F., 2013. How rural is the EU RDP? An analysis through spatial fund allocation. Bio-based and Applied Economics 2(3): 277-300.

Churski P., 2005. Problem areas in Poland in terms of the objectives of the European Union's regional policy. European Planning Studies 13(1): 45-72.

Crescenzi R., 2009. Undermining the principle of concentration? European Union regional policy and the socio-economic disadvantage of European regions. Regional Studies 43(1): 111-133.

Crescenzi R., De Fillipis F., Pierangeli F., 2015. In tandem for cohesion? Synergies and conflicts between regional and agricultural policies of the European Union. Regional Studies 49(4): 681-704.

Czyż T., Hauke J., 2011. Evolution of regional disparities in Poland. Quaestiones Geographicae 30(2): 35-48.

De Propris L., 2007. Reconciling cohesion and competitiveness through EU cluster policies? Policy Studies 28(4): 327-345.

Dellmuth L.M., Stoffel M.F., 2012. Distributive politics and intergovernmental transfers: The local allocation of European Union structural funds. European Union Politics 13(3): 413-433.

Duran M., 2014. The absorption capacity of Turkey for its use of the European Union pre-accession assistance. Bogazici Journal of Economics and Administrative Sciences 28(1): 69-93.

Enflo K., Hjertstrand P., 2009. Relative sources of European regional productivity convergence: A bootstrap frontier approach. Regional Studies 43(4): 643-659.

Esposti R., Bussoletti S., 2008. Impact of Objective 1 funds on regional growth convergence in the European Union: A panel-data approach. Regional Studies 42(2): 159-173.

Ezcurra R., 2009. Does income polarization affect economic growth? The case of the European regions. Regional Studies 43(2): 267-285.

Fischer M.M., Stirböck C., 2006. Pan-European regional income growth and club-convergence. The Annals of Regional Science, 40(4): 693-721.

Fratesi U., 2008. Regional policy from a supra-regional perspective. The Annals of Regional Science 42(3): 681-703.

Fujita M., Krugman P., 2004. The new economic geography: Past, present and the future. Papers in Regional Science 83(1): 139-164. 
Geppert K., Stephan A., 2008. Regional disparities in the European Union: Convergence and agglomeration. Papers in Regional Science 87(2): 193-217.

Hudson R., 2007. Regions and regional uneven development forever? Some reflective comments upon theory and practice. Regional Studies 41(9): 1149-1160.

Iatu C., Alupului C., 2011. Structural funds' absorption in Romania: Factor analysis of NUTS 3 level. Transformations in Business \& Economics 10(2b): 612-630.

Jaliu D., Radulescu C., 2013. Six years in managing structural funds in Romania. Lessons learned. Transylvanian Review of Administrative Science 9(38): 79-95.

Jurevičienė D., Pileckaitė J., 2013. The impact of EU structural fund support and problems of its absorption. Business, Management and Education 11(1): 1-18.

Kaufmann A., Wagner P., 2005. EU regional policy and the stimulation of innovation: The role of the European Regional Development Fund in the Objective 1 Region Burgenland. European Planning Studies 13(4): 581-599.

Klímová V., Žítek V., 2015. Inovační paradox v Česku: Ekonomická teorie a politická realita. Politická ekonomie 63(2): 147-166.

Krugman P., 1991. Increasing returns and economic geography. Journal of Political Economy 99(3): 483-499.

Lambrinidis M., Psycharis Y., Rovolis A., 2005. Regional allocation of public infrastructure investment: The case of Greece. Regional Studies 39(9): 1231-1244.

Lolos S.E.G., 2009. The effect of EU structural funds on regional growth, assessing the evidence from Greece, 1990-2005. Economic Change Restructuring 42(3): 211-228.

Lošták M., Hudečková H., 2010. Preliminary impacts of the LEADER+ approach in the Czech Republic. Agricultural Economics 56(6): 249-265.

Maillat D., 1998. Innovative milieu and new generations of regional policies. Entrepreneurship \& Regional Development 10(1): 1-16.

Martín C., Sanz I., 2003. Real convergence and European integration: The experience of the less developed EU members. Empirica 30(3): 205-236.

Milio S., 2007. Can administrative capacity explain differences in regional performances? Evidence from structural funds implementation in Southern Italy. Regional Studies, 41(4): 429-442.

Modranka E., 2015. Spatial dependencies in the absorption of funds from Regional Operational Programmes on NUTS 3 regional level in Poland. Journal of Economics \& Management 19(1): 108-122.

Moulaert F., Mehmood A., 2010. Analysing regional development and policy: A structural-realist approach. Regional Studies 44(1): 103-118.

Novák J., Netrdová P., 2011. Prostorové vzorce sociálně-ekonomické diferenciace obcí v České republice (Spatial patterns of socioeconomic differentiation in the Czech
Republic at the level of municipalities). Czech Sociological Review 47(4): 717-744.

Novosák J., Hájek O., Smékalová L., Nekolová J., Škarka M., 2015. Territorial cohesion and the geography of EU Cohesion Policy funding in the Czech Republic. Transformations in Business \& Economics 14(3C): 42-59.

Novosák J., Hájek O., Horváth P., Nekolová J., 2017. Structural Funding and intrastate regional disparities in post-communist countries. Transylvanian Review of Administrative Sciences 13(51): 53-69.

Parr J.B., 1999. Growth-pole strategies in regional economic planning: A retrospective view. Part 1. Origins and advocacy. Urban Studies 36(7): 1195-1215.

Pawlicz A., 2014. Selected determinants of absorption of EU - tourism-related projects. The case of counties in West Pomerania and Lubuskie, Poland. Service Management 12: 61-69.

Popescu A.S., 2015. The absorption capacity of European funds - concepts. Annals-Economy Series 18(3): 119-125.

Porter M.E., 1990. The competitive advantage of nations. Harvard business review 68(2): 73-93.

Puga D., 2002. European regional policies in light of recent location theories. Journal of Economic Geography 2(4): 373406.

Pugicerver-Peňalver M.C., 2007. The impact of structural funds policy on European regions' growth. A theoretical and empirical approach. The European Journal of Comparative Economics 4(2): 179-208.

Schraff D., 2014. Buying turnout or rewarding loyalists? Electoral mobilization and EU structural funding in the German Länder. European Union Politics 15(2): 277-288.

Simmie J., Carpenter J., 2008. Towards an evolutionary and endogenous growth theory explanation of why regional and urban economies in England are diverging. Planning, Practice \& Research 23(1): 101-124.

Smetkowski M., 2013. Regional disparities in Central and Eastern European countries: Trends, drivers and prospects. Europe-Asia Studies 65(8): 1529-1554.

Tatar M., 2010. Estonian local government absorption capacity of European Union structural funds. Halduskultuur Administrative Culture 11(2): 202-226.

Tödling F., Trippl M., 2005. One size fits all? Towards a differentiated regional innovation policy approach. Research Policy 34(8): 1203-1219.

Tosun J., 2014. Absorption of regional funds: A comparative analysis. Journal of Common Market Studies 52(2): 371-387.

Václavík J., 2015. Indirect support of research and development in the Czech Republic. Scientia et Societas 11(2): 110-125.

Zaman G., Georgescu G., 2009. Structural fund absorption: A new challenge for Romania? Romanian Journal of Economic Forecasting 10(1): 136-154. 